\title{
Earthquake-reactivated landslide scenarios in Southern Italy based on spectral-matching input analysis
}

\author{
F. Bozzano - C. Esposito - G. Martini - S. Martino • A. Prestininzi • \\ D. Rinaldis · R. W. Romeo - G. Scarascia Mugnozza
}

Received: 13 December 2012 / Accepted: 23 June 2013 / Published online: 10 July 2013

(C) The Author(s) 2013. This article is published with open access at Springerlink.com

\begin{abstract}
The Tyrrhenian portion of the Calabria region (southern Italy) is particularly prone to landslides as a consequence of intense morphodynamic processes. These processes affect the slopes that are composed of highly jointed metamorphic rock masses. Moreover, the frequent intense rainfalls and the up to Mw 7.0 regional earthquakes represent the main landslide triggering factors. An area of approximately $45 \mathrm{~km}^{2}$ was selected as a test site in the context of a regional project aimed at reconstructing possible earthquake-reactivated landslide scenarios (i.e., referred to already existing landslide masses). An inventory map led to the identification of 175 landslides, including rock slides, earth slides and rock falls. Groundmotion scenarios based on a spectral-matching method were derived to evaluate the expected earthquake-induced displacements of the existing landslides. Naturally recorded acceleration time histories were selected from international ground-motion databases based on a similarity index and considered representative of the seismological features of the considered seismic sources (i.e., epicentral distance, magnitude, focal mechanism). Spectral attenuation was considered, according to well-established attenuation laws, to define the expected response spectrum at the outcropping bedrock corresponding to each existing landslide. Subsequently, the selected natural records were modified to guarantee spectral matching with the attenuated response spectra at each landslide site. The derived time histories were used to compute coseismic displacements via the classic Newmark's sliding-block method. Different scenarios of co-seismic landslide displacements or collapse were generated for different pore-water pressure hypotheses. The strongest $\mathrm{Mw}>6$ seismic scenario (Messina Straits seismogenic source) indicated an exceedance probability of earthquake-induced co-seismic landslide
\end{abstract}

F. Bozzano - C. Esposito - S. Martino $(\varangle) \cdot$ A. Prestininzi · G. Scarascia Mugnozza Department of Earth Sciences and Research Centre for Geological Risks (CERI), University of Rome "Sapienza", P.le A. Moro 5, 00185 Rome, Italy

e-mail: salvatore.martino@uniroma1.it

G. Martini · D. Rinaldis

Energy and Sustainable Economic Development (ENEA),

Italian National Agency for New Technologies, Rome, Italy

R. W. Romeo

Department of Earth Sciences, Life and Environment,

University of Urbino "Carlo Bo", Urbino, Italy 
collapse varying from 20 to $55 \%$ with the increasing severity of the pore-water pressures. This probability corresponds to a percentage of co-seismic landslide displacements up to $40 \%$ of the total inventoried landslides. The exceedance probability indicated that co-seismic landslide collapse drops below $20 \%$ for $\mathrm{Mw}<6$ seismic scenarios. In contrast, if a uniform probability is assumed for the seismic action occurrence, i.e., return periods of 475 and 2,475 years, the total percentage of landslide co-seismic displacements could be as high as 70 and $90 \%$, respectively, for the considered pore-water pressures.

Keywords Landslide inventory · Earthquake-induced landslides · Newmark's method · Spectral-matched seismic input · Southern Italy

\section{Introduction}

The expected co-seismic displacements of slopes are commonly computed by applying Newmark's sliding block method (Newmark 1965). According to this method, the landslide mass is assimilated to a rigid block sliding on an inclined plane. The block has a critical acceleration $\left(a_{y}\right)$ expressed by the critical seismic coefficient $k_{y}\left(a_{y} / g\right)$, which represents the threshold seismic action required for sliding initiation. Newmark's method makes it possible to calculate the cumulative co-seismic permanent displacement of a landslide mass forced by an acceleration time history.

Based on Newmark's method, some empirical equations have been proposed after solving multiple regressions (Jibson 1993; Jibson et al. 1998; Romeo 2000; Hsieh and Lee 2011) to provide Newmark's displacement $\left(\mathrm{D}_{\mathrm{N}}\right)$ for given values of critical acceleration and groundshaking parameters (i.e., PGA or Arias intensity). This approach (simplified Newmark's analysis) represents a useful tool for computing $\mathrm{D}_{\mathrm{N}}$-values over large areas through the use of geographic information systems (GIS) and by performing a hazard-mapping procedure (Luzi and Pergalani 1999; Jibson et al. 2000). In this procedure, both $\mathrm{k}_{\mathrm{y}}$ and expected PGA are attributed to a spatial grid, and $\mathrm{D}_{\mathrm{N}}$ is automatically computed by applying the empirical regressions. More specifically, $\mathrm{k}_{\mathrm{y}}$ is derived from a combination of a slope-gradient map (obtained by a digital elevation model) with the pre-seismic stability conditions of slopes, which are derived, in turn, from the shear strength properties of the outcropping lithologies. In the same way, PGA-values are attributed to each grid node by applying a ground-motion attenuation relationship with the proper seismic scenario parameters (i.e., magnitude-distance pairs as a minimum).

The reliability of this approach was tested in California (Jibson et al. 1998, 2000; Miles and Ho 1999; Jibson 2007), taking into account well-documented seismically induced landslide effects due to the Northridge earthquake of 17 January 1994. Maps of the slope collapse probabilities based on $\mathrm{D}_{\mathrm{N}}$ were also proposed and referred to the ground-shaking scenario of interest. The probabilistic seismic landslide hazard-mapping procedure for Newmark's coseismic slope displacements has been applied by many researchers (Capolongo et al. 2002; Saygili and Rathje 2009; Wang and Lin 2010; Romeo et al. 2011; Vollmert et al. 2011). While these applications have generally referred to first time slope failures (Skempton 1985; Hutchinson 1988) and have not been specifically devoted to the analysis of co-seismic displacements of pre-existing landslide masses, in this study the interest has been focused on the co-seismic displacements of pre-existing landslide masses, due to their complex interactions with the seismic waves. Such an interaction can cause significant differences in expected coseismic displacements with respect to Newmark's method (Lenti and Martino 2011, 2013), depending on morphological features of the slopes as well as on physical parameters of the seismic input (i.e., characteristic period and Arias intensity). 


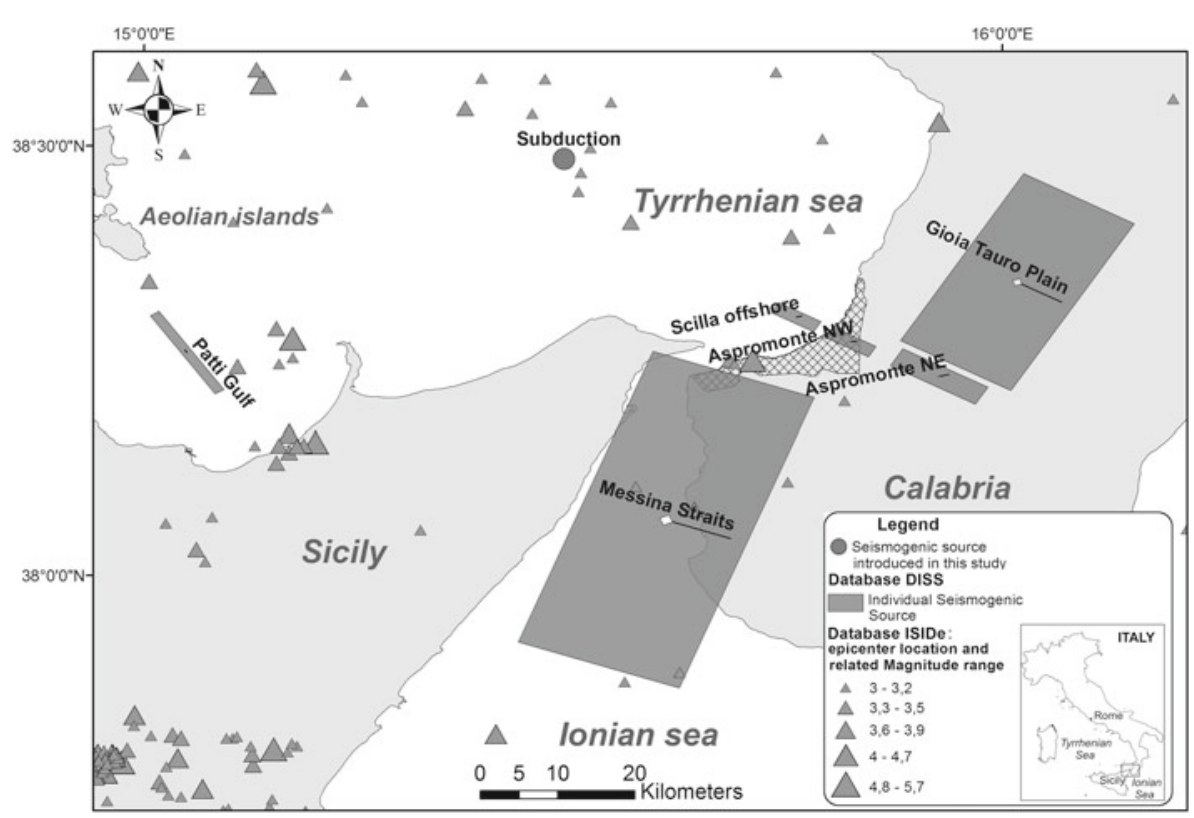

Fig. 1 Map displaying the seismogenic sources selected from the DISS3.1 database and considered for this study (the Subduction seismogenic source considered in this study but not selected from the DISS3.1 is also shown). The epicentre location (from the ISIDe database, 2010) of earthquakes with $\mathrm{Mw} \geq 3.0$ is also shown. The oblique gridded polygon comprises the study area

Based on these considerations, the southern Tyrrhenian portion of the Calabria region of Italy (Fig. 1), was selected as a test site in the framework of a regional project devoted to provide scenarios of co-seismic landslide displacements (including the general landslide collapses), as the frequent intense rainfalls and the local earthquakes represent the main triggering factors of landslide events. In particular, the area is exposed to earthquake magnitudes as high as 7 , as shown by the catastrophic sequence of earthquakes in the 1783 "Terremoto delle Calabrie" and more recently by the 1908 Messina Straits earthquake.

To perform this study, a landslide inventory map was compiled and naturally recorded acceleration time histories matching the expected response spectra were specifically selected for each landslide and each considered earthquake scenario. Moreover, the role of porewater pressures within the slopes was taken into account by considering a variation of the $r_{u}$ parameter along the sliding surface.

\section{Geological setting of the study area}

The study area corresponds to the southern Tyrrhenian portion of the Calabria region of Italy, a sector of the Calabro-Peloritano Arc. This sector can be considered a fore-arc/back-arc basin system, and the corresponding geodynamic evolution is related to a complex combination of compressive and normal tectonic features due to the lithospheric subduction of the Ionian oceanic crust under the Calabrian Arc (Monaco et al. 1996). The subduction plane dips steeply northwestward up to a depth of more than $600 \mathrm{~km}$ below the Tyrrhenian Sea.

The stratigraphy of the study area along the coastal area between the towns of Palmi and Villa S. Giovanni (Fig. 2) is characterised by cemented rocks and soils (fine and coarse 


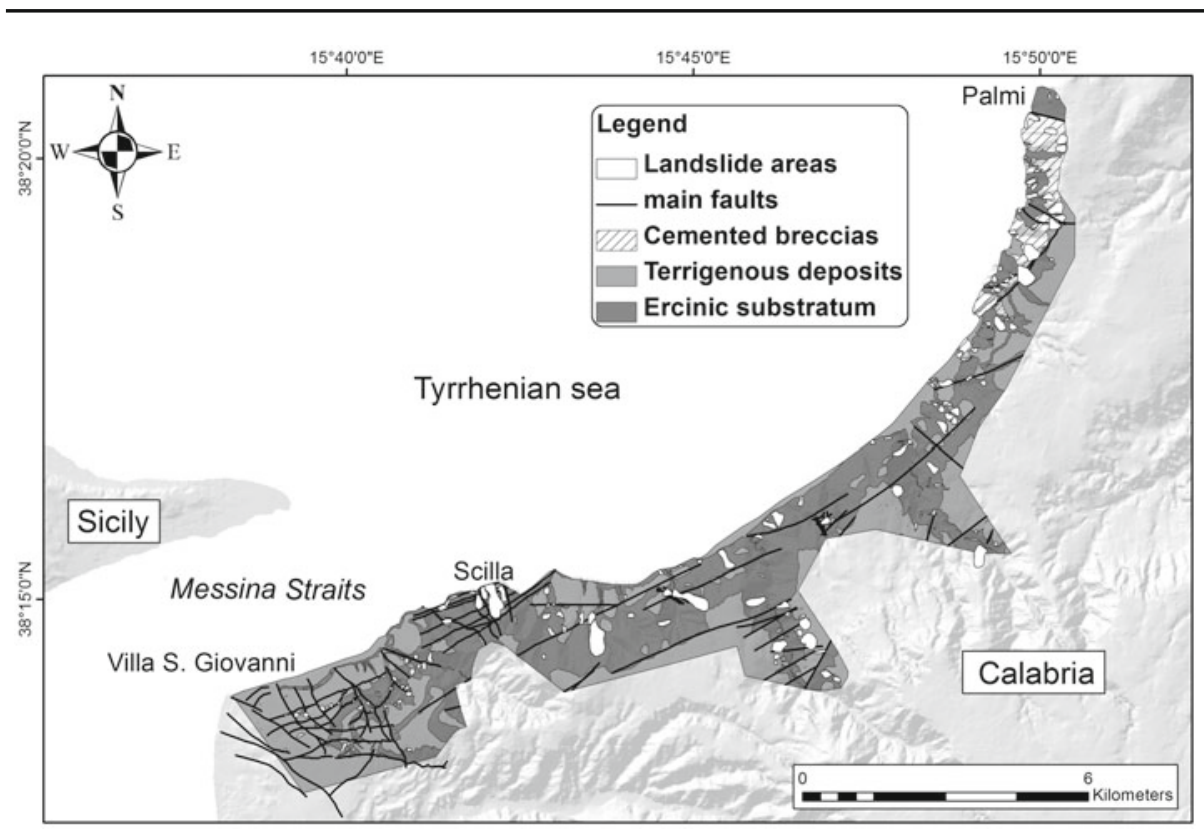

Fig. 2 Simplified geological scheme and landslide inventory map of the study area

grained) attributed to the Ercinic-Holocene time interval. The Palaeozoic basement is part of the Aspromonte metamorphic unit (Lentini et al. 2002; Carbone et al. 2008). These metamorphic rocks consist of gneiss and are characterised by a predominant isotropic, granular texture, including biotitic micas, plagioclasic minerals and rounded xenoliths. A major Alpine foliation is also detectable, and wide zones of highly jointed rocks generally correspond to the main fault traces. A thick succession of terrigenous deposits widely outcrop in the study area and includes conglomerates, marls and sands of Tortonian-Pliocene age. The widespread outcropping of the Ercinic substratum in the considered area reflects the Campo Piale horst structure, which is bounded to the north by the border fault system of the Gioia TauroMesima Basin and to the south by the Mortille border fault system of the Reggio Calabria Basin (Ghisetti 1979, 1981, 1984; Guarnieri et al. 2004; Carbone et al. 2008).

The area is also characterised by the outcropping of marine terrace deposits related to many hierarchical orders (Miyauchi et al. 1994; Dumas et al. 2005) and is composed of reddishbrown gravels and sands with a sub-horizontal bedding attitude. These marine deposits lie over the Ercinic metamorphic substratum with an unconformity surface whose bottom layer is defined by a one-metre-thick bed of pebbles.

The intense tectonic evolution of this area is responsible for pervasive jointing of the rock masses, which is particularly marked astride the main fault lines. Moreover, the area of interest along the coastline is characterised by wide outcrops of gneiss breccias cemented by calcite.

\section{Slope instabilities in the study area}

Several landslides affect the study area due to the morphological features of the relief (deepening rivers and cliff slopes) as well as the geomechanical properties of the outcropping rock masses (highly jointed rocks or poorly cemented granular deposits). Thus far, 175 landslides 

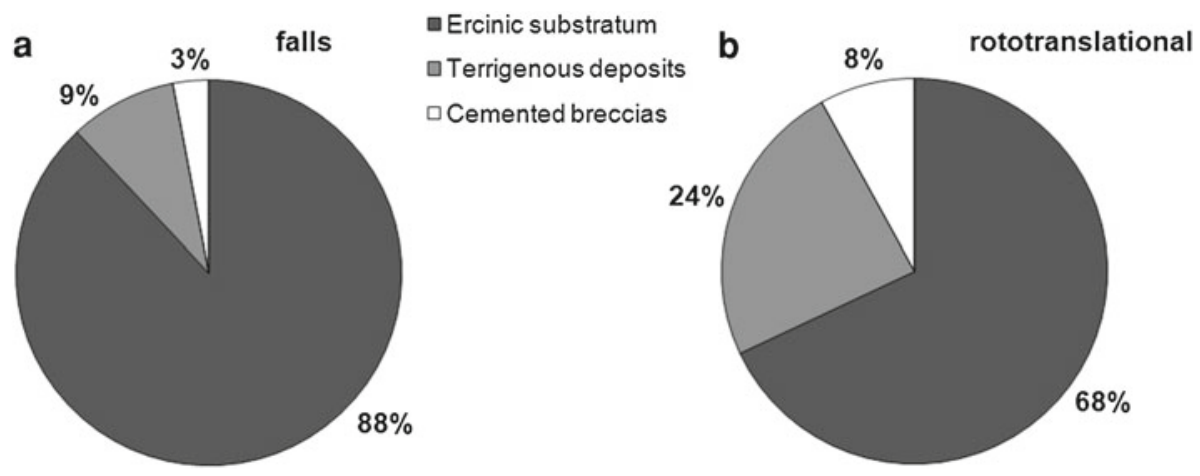

Fig. 3 Percentages of rock-falls (a) and roto-translational landslides (b) involving different lithologies

have been recognised and divided into 57 rock falls and 118 slides over an area of approximately $45 \mathrm{~km}^{2}$. The incidence of the landslides for the whole study area is approximately $6 \%$. Furthermore, approximately $75 \%$ of the total number of landslides involve the metamorphic substratum, representing $68 \%$ of the inventoried slides and $88 \%$ of the rock falls (Fig. 3).

The largest event within the study area is represented by the Mt. Pacì rockslide triggered by the earthquake that occurred on 6 February 1783 during the "Terremoto delle Calabrie" seismic sequence. This rockslide involved approximately $8 \mathrm{Mm}^{3}$ and induced a tsunami wave responsible for more than 1,500 casualties in the adjacent Marina Grande beach area close to Scilla (Gerardi et al. 2008; Graziani et al. 2006; Bozzano et al. 2011; Mazzanti and Bozzano 2011).

In order to complete the cognitive framework of such an unstable area, a landslide susceptibility analysis for both the roto-translational slides and rock falls was carried out using a statistical approach, such as the logistic regression technique, widely adopted in landslidesusceptibility and/or hazard-related studies (see, for example, Mathew et al. 2009, and references therein). As explanatory variables (i.e. predisposing factors), use was made of lithology, land-cover, morphological (elevation, curvature and slope topographic position index) and hydrological (flow accumulation) parameters (Lee and Talib 2005). The Euclidean distance from the nearest main fault was also calculated for each mapping unit and considered during the analysis, as this value can be considered as a proxy of the rock mass jointing, which is especially relevant for the rock falls.

The susceptibility models (one for roto-translational slides and one for rock falls) were first trained on datasets based on randomly sampled landslide-affected and stable points.

Once the probability of landslide occurrence was calculated for each mapping unit and, thus, for the whole study area, the models were validated by randomly sampling a different dataset of landslide-affected and stable points (Chung and Fabbri 2003). The accuracy of both models was then assessed by the construction of receiver operating characteristic (ROC) curves and the related area under curve (AUC) values, which displayed a satisfactory performance.

Table 1 summarises the composition of the training and test datasets, and Fig. 4 shows the susceptibility maps for each considered landslide type and the related ROC curves.

It is worth stressing that the susceptibility analysis was also aimed at defining the most critical zones where the attention should be focused in a further study phase, which would deal with the seismic triggering of newly formed (or new generation) slope failures. This analysis found that south-facing steep rock slopes close to the main tectonic lines are more prone to 
Table 1 Composition of the training and test datasets considered for the susceptibility analysis of the study area

\begin{tabular}{lll}
\hline Rock falls & "Landslide" samples & "No landslide" samples \\
\hline Training & 330 & 498 \\
Test & 250 & 390 \\
\hline Rototranslational slides & "Landslide" samples & "No landslide" samples \\
\hline Training & 330 & 498 \\
Test & 250 & 390 \\
\hline
\end{tabular}

rock falls, whereas roto-translational slides are linked to more causal factors, ranging from lithology to land cover characteristics. Moreover, the highest concentrations of existing landslides correspond well to the areas characterised by the highest susceptibility to landslides.

\section{Scenarios of seismically reactivated landslides}

\subsection{Spectral-matched accelerometric time histories}

In this study, six seismic sources were considered according to the Database of Individual Seismogenic Sources (DISS3.1 by DISS Working Group 2010) shown in Fig. 1. The seismic parameters are listed in Table 3. A further seismic source was not considered in the DISS3.1 DB. The source was located off the Calabrian Coast in the Tyrrhenian Sea and related to the slab of the Ionian plate subducting beneath the Calabrian Arc.

Uniform Hazard Spectra were selected from the National Seismic Hazard map of Italy (Meletti and Montaldo 2007; Montaldo and Meletti 2007) based on the closest sites to the surface projection of the rupture area for each source. This procedure accounts for the selection of accelerometric time histories in the vicinity of the seismic source to be further attenuated at each landslide site, provided that they refer to the occurrence of ground motion for a selected probability to be exceeded within a reference time period (e.g., $10 \%$ exceedance probability in 50 years or an annual rate of exceedance of 0.0021 , corresponding to a return period of 475 years).

To select a suitable number of time histories representative of the modelled seismic sources, the following criteria were adopted: (1) a moment-magnitude consistent with the characteristic earthquake of each source (see Table 2), (2) a distance closer than $30 \mathrm{~km}$ from the source to include possible near-source effects and (3) reference site conditions (e.g., stiff or rocky) to avoid possible site effects. To have a great number of natural time-histories available (especially in the case of Mw $>6$ earthquakes), the European Strong-Motion DB (Ambraseys et al. 2000), COSMOS (http://db.cosmos-eq.org), PEER (http://peer.berkeley.edu/smcat) and Kyoshin Network K-NET (http://www-k-net.bosai.go.jp/k-net/index.en.shtml) databases were considered. The selection provided a set of time histories for each seismic source, whose number was reduced to five for each source by adopting a procedure of residual minimisation. The response spectra of the selected time histories of each source were compared with the consistent 475-yrs UHS, and the following index (called the 'similarity index', Rinaldis et al. 2011) was computed for each jth time-history:

$$
I Q R_{j}=\frac{\sqrt{\sum_{i=1}^{N}\left[S a_{U H S}\left(T_{i}\right)-S a_{j}\left(T_{i}\right)\right]^{2} / N}}{\sum_{i=1}^{N}\left[S a_{j}\left(T_{i}\right)\right] / N}
$$



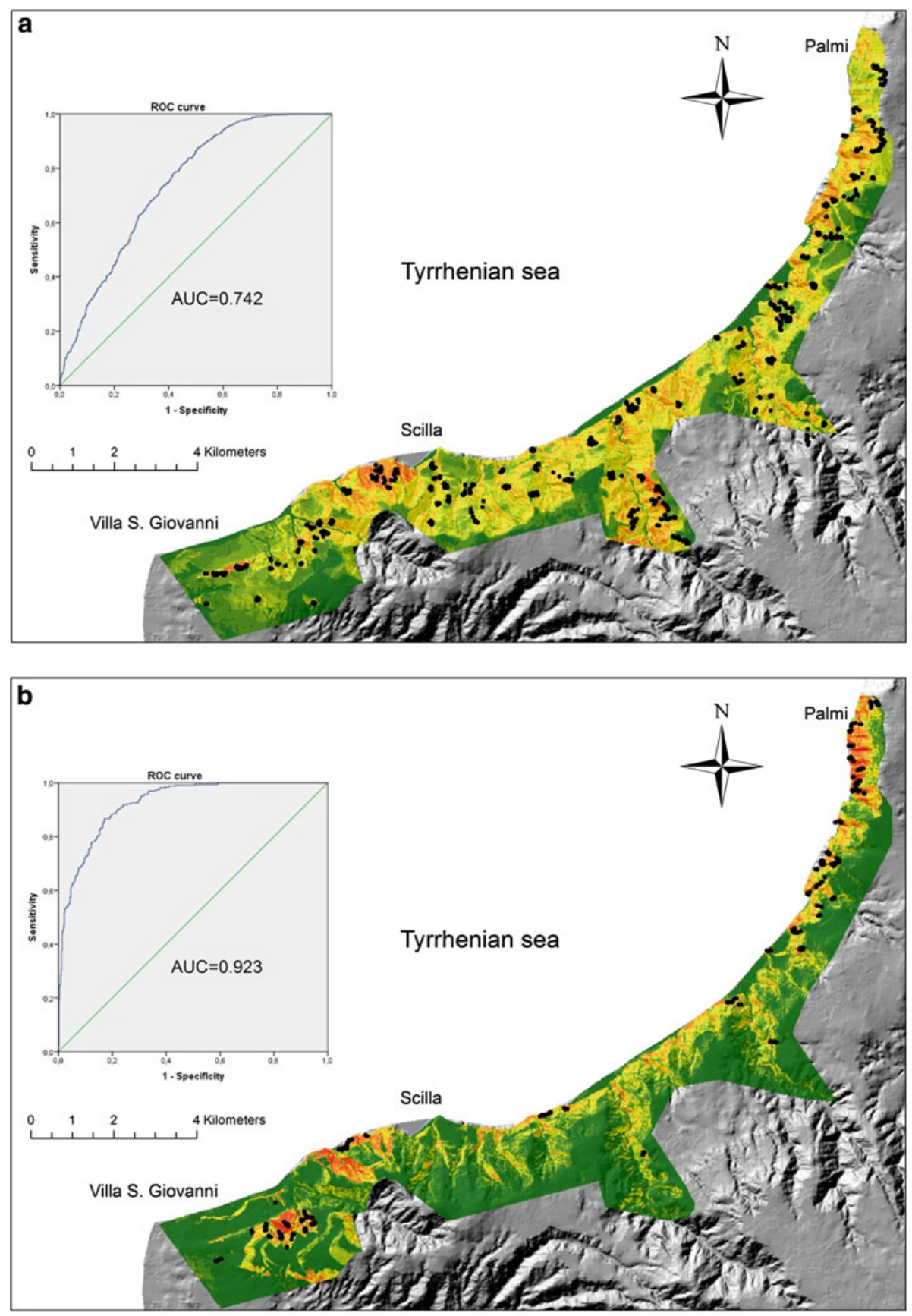

Legend

Classes of spatial probability of landslide occurrence

$0-10 \% \square 20-30 \% \square 40-50 \% \square 60-70 \% \square 80-90 \%$
$10-20 \% \square 30-40 \% \square 50-60 \% \square 70-80 \% \square 90-100 \%$$\quad$. sampled landslide points

Fig. 4 Landslide susceptibility maps referred to slides (a) and rock falls (b) obtained for the study area and the related ROC curves 
Table 2 The considered seismic sources (Mw from DISS3.1-database) and related epicentral distances (EPD) from the study area

\begin{tabular}{lllrr}
\hline Name & Reference earthquake & $\begin{array}{l}\text { DISS 3.1 } \\
\text { seismogenic source }\end{array}$ & Mw & EPD (km) \\
\hline Messina straits (MS) & $28 / 12 / 1908$ & ITIS013 & 7.0 & 27 \\
Gioia Tauro (GT) & $05 / 02 / 1783$ & ITIS012 & 6.6 & 30 \\
Gulf of Patti (PT) & $15 / 04 / 1978$ & ITIS045 & 6.1 & 81 \\
Subduction (SBD) & $26 / 10 / 2006$ & - & 6.0 & $>100$ \\
Aspromonte NE (ASP_NE) & $16 / 11 / 1984$ & ITIS042 & 5.8 & 18 \\
Aspromonte NW (ASP_NW) & $06 / 02 / 1783$ & ITIS040 & 5.3 & 6 \\
Scilla off-shore (SC) & $16 / 11 / 1984$ & ITIS041 & 5.3 & 5 \\
\hline
\end{tabular}
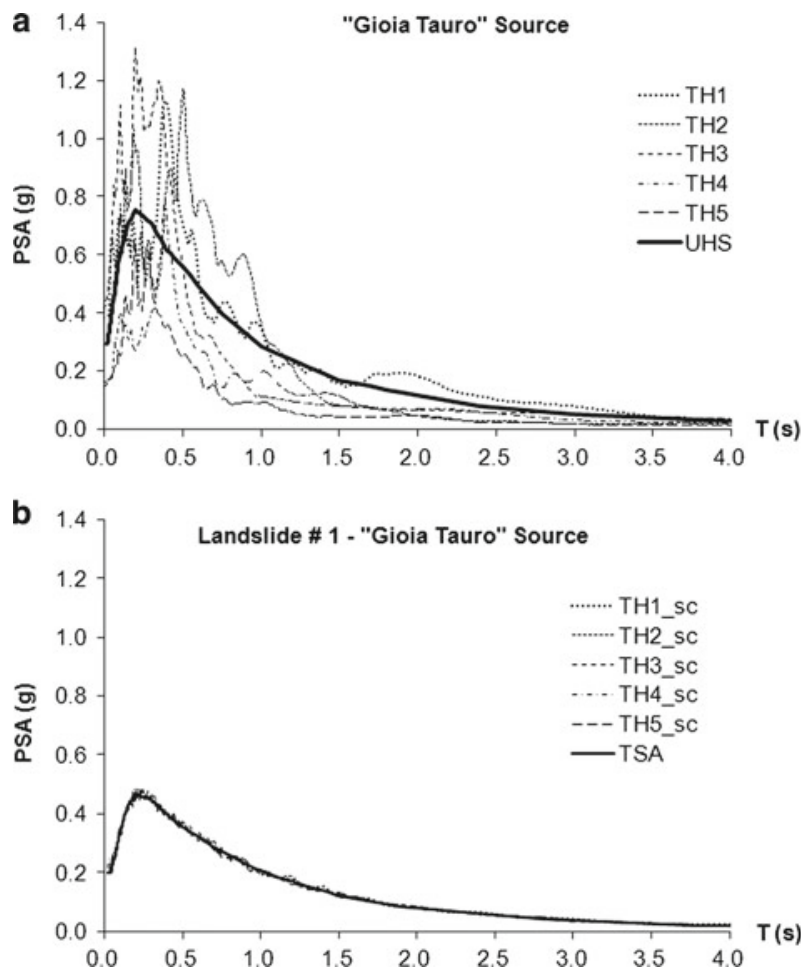

Fig. 5 a Examples of the response spectra of five time histories from global catalogues best fitting the shape of the 90th percentile UHS for the Gioia Tauro seismic source; b spectrum-compatible response spectra of the selected time histories calculated by the attenuated spectrum for landslide \# 1

where $\mathrm{Sa}_{\mathrm{j}}\left(\mathrm{T}_{\mathrm{i}}\right)$ is the response spectrum acceleration of the jth time-history at the ith period $\mathrm{T}$ and $\mathrm{Sa}_{\mathrm{UHS}}\left(\mathrm{T}_{\mathrm{i}}\right)$ is the UHS target spectrum acceleration at the same period. Only five of the time histories selected for each seismic source were chosen based on their lowest IQR values (Fig. 5a).

Subsequently, for each landslide site, the time histories determined for each seismic source were made spectrum compatible to the site-response spectra, these last ones computed using 
spectral attenuation relationships (Sabetta and Pugliese 1996) given the magnitude-distance pair for each landslide site and for each seismic scenario. The spectrum compatibility of the time histories was obtained by applying the WES RASCAL Code (Silva and Lee 1987) as adapted by Naeim and Lew (1995) and further modified by Rinaldis et al. (2011), whose modification consisted of subtracting or adding amplitudes without any phase shifting (Fig. 5b).

This procedure, in comparison to the classical approach of selecting the time histories directly for the site of analysis, has the advantage of simulating the propagation from the source to the site, preserving the intrinsic variability of the earthquake motion due to different earthquakes from the same source (inter-event variability).

Finally, given the 4130 accelerometric time histories determined for all 118 landslide sites, excluding rock fall sites, those with the highest Arias intensity value were selected for each landslide site bedrock and each seismic scenario for a total of 826 time histories for the dynamic displacement analyses described below.

\subsection{Earthquake-induced landslide displacements}

To evaluate the slope stability conditions of the existing landslide masses under dynamic conditions, a limit equilibrium analysis using conventional methods, i.e., Bishop's method 1955 or Janbu's method 1954, depending on the landslide mass geometry, (Budhu 2011)] was carried out for roto-translational landslides alone under the assumption of a rigid block model, i.e. by neglecting plastic internal deformations of the landslide mass. At this aim, a geological cross-section was derived for each landslide, the sliding surface was defined starting from the mapped geomorphological evidences (i.e. crown area, length and width of the landslide mass, kinematic features) and the mechanical properties were diversified along the sliding surface by taking into account the different involved lithologies. In this context, two actions were taken into account: hydraulic forces, accounted for by the pore-pressure parameter $\mathrm{r}_{\mathrm{u}}$ (Bishop 1955), and seismic forces, accounted for by the inertial forces applied at the centre of gravity of the landslide mass and proportional to the horizontal seismic coefficient $k_{h}$ (the ratio of earthquake horizontal acceleration to the gravity acceleration). In the first step, a sensitivity analysis was performed by evaluating the variation of the safety factor (SF) with each considered parameter (i.e., $r_{u}$ and $k_{y}$ ). In the second step, the combination of the two parameters was considered to lead to the construction for each landslide of a set of "critical" $r_{u}-k_{y}$ values (Fig. 6) for the limit-state condition $S F=1$. The parameter values summarised in Table 3 were used for the geomechanical characterisation of the landslide masses. In particular, the mechanical properties of the jointed rock masses of the Ercinic substratum were attributed according to the Hoek and Brown (Hoek et al. 2002) equivalent approach by considering the values of the geomechanical indexes Ib and $\mathrm{Jv}$ as measured in the landslide areas according to the ISRM (2007) standard. The used geomechanical parameters have been validated in previous studies focused on some of the here considered landslides (Bozzano et al. 2011, 2012).

The determined "critical" $r_{u}-k_{y}$ values were constrained by two thresholds: the maximum admissible value of $r_{u}$, depending on the topography of the slopes, and the maximum critical acceleration, which is constrained by the ground acceleration for the considered return periods (Fig. 6 exemplifies the case of a return period equal to 475 years).

On this basis, a displacement analysis applying the rigorous sliding-block method (Newmark 1965, as modified by Wilson and Keefer 1985) was performed for each landslide and for each seismogenic source scenario, taking into account the variability of pore pressure conditions through the $r_{u}$ coefficient. A parametric analysis was carried out for each landslide by changing the $r_{u}$ values from 0 up to the maximum admissible value. 


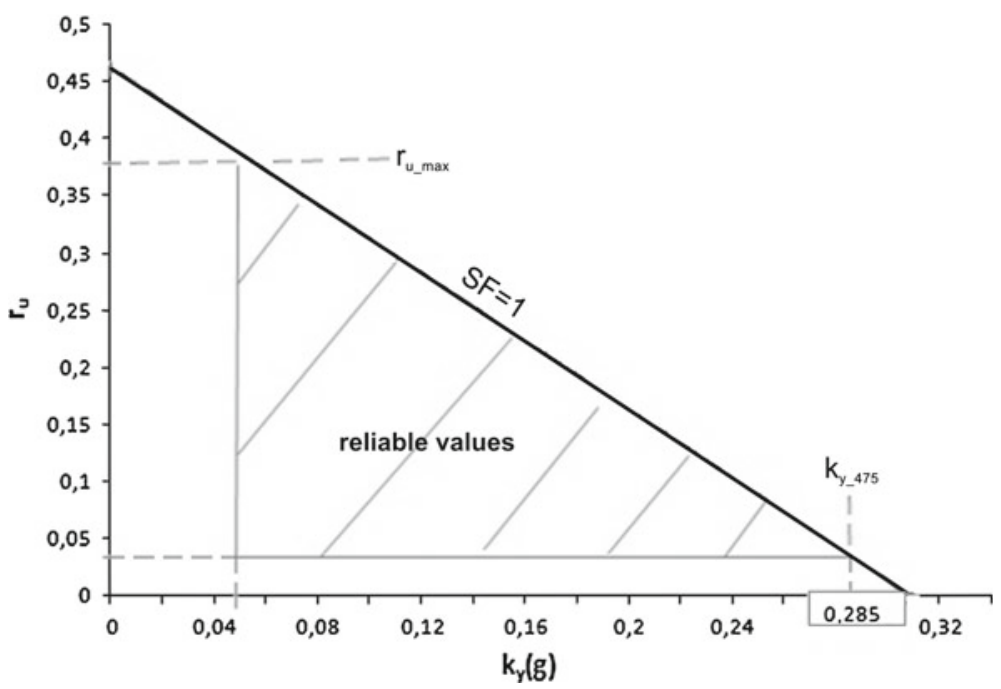

Fig. 6 Example of an $r_{u}-k_{y}$ curve derived for one of the landslide masses identified within the study area; the limit values of $r_{u}$ and $k_{y}$ (referring to a return period of 475 years) are also indicated

Table 3 Geomechanical parameters attributed to the rock mass classes according to the (Hoek et al. 2002) equivalent approach

\begin{tabular}{|c|c|c|c|c|c|c|c|c|c|c|}
\hline & \multicolumn{2}{|l|}{$\mathrm{lb}$} & \multicolumn{2}{|l|}{$\mathrm{Jv}$} & \multicolumn{2}{|l|}{$\phi$} & \multicolumn{2}{|l|}{$\mathrm{c}$} & \multicolumn{2}{|l|}{$\mathrm{s}_{\mathrm{t}}$} \\
\hline & $\mathrm{cm}$ & $s t d v$ & joint $/ \mathrm{m}^{3}$ & $s t d v$ & $\left({ }^{\circ}\right)$ & $s t d v$ & (MPa) & $s t d v$ & $(\mathrm{MPa})$ & $s t d v$ \\
\hline Ercinic substratum & 12 & 5.0 & 19 & 7.9 & 48 & 8.8 & 0.30 & 0.100 & 0.013 & 0.0121 \\
\hline Cemented breccias & I & l & l & l & 34 & 5.5 & 0.18 & 0.021 & 0.002 & 0.0008 \\
\hline Terrigenous deposits & / & l & / & l & 36 & l & 0.00 & / & 0.000 & / \\
\hline
\end{tabular}

$I b$ block index, $J v$ number of joints for cubic meter, $\phi$ friction angle, $c$ cohesion, $s_{t}$ tensile strength and related standard deviations (stdv)

The computed co-seismic displacements were analysed to provide information on the percentage of seismically re-activated landslides and on the spatial extent of the area corresponding to the failed slopes. The amount of displacement allows to distinguish between co-seismic displacements and co-seismic landslide collapses, these last ones determined according to the critical displacement values provided by Romeo (2000). The most severe scenario is represented by the $\mathrm{Mw}=7$ Messina Straits earthquake (Fig. 7), for which the percentage of reactivated landslides range from 16 to $32 \%$ for $r_{u}$-values varying from zero (dry conditions) to 0.4 (very severe admissible conditions), whereas the percentage of collapses varies between 10 and $20 \%$ in the same $r_{u}$-conditions (Fig. 8). Similar results were obtained for the $\mathrm{Mw}=6.6$ Gioia Tauro earthquake scenario; differently but for the $\mathrm{Mw}$ $=5.8$ Aspromonte NE earthquake, the percentage of co-seismic landslide displacements ranges from 9 to $18 \%$, and the percentage of co-seismic landslide collapses varies from 2 to $8 \%$ (Fig. 8). The influence exerted by the source-to-landslide distance is clear when comparing these results with those of the $\mathrm{Mw} \geq 6$ earthquake scenarios at distances greater than $50 \mathrm{~km}$ (Gulf of Patti and subduction source) where the percentage of reactivated landslides does not exceed $14 \%$ and the percentage of co-seismic landslide collapses is less than $3 \%$. 



Fig. 7 Maps of Newmark's displacements (D) computed for roto-translational landslides and for the Messina Straits seismogenic source in the case of $r_{u}=0(\mathbf{a}), r_{u}=0.2(\mathbf{b})$ and $r_{u}=0.4(\mathbf{c})$ 

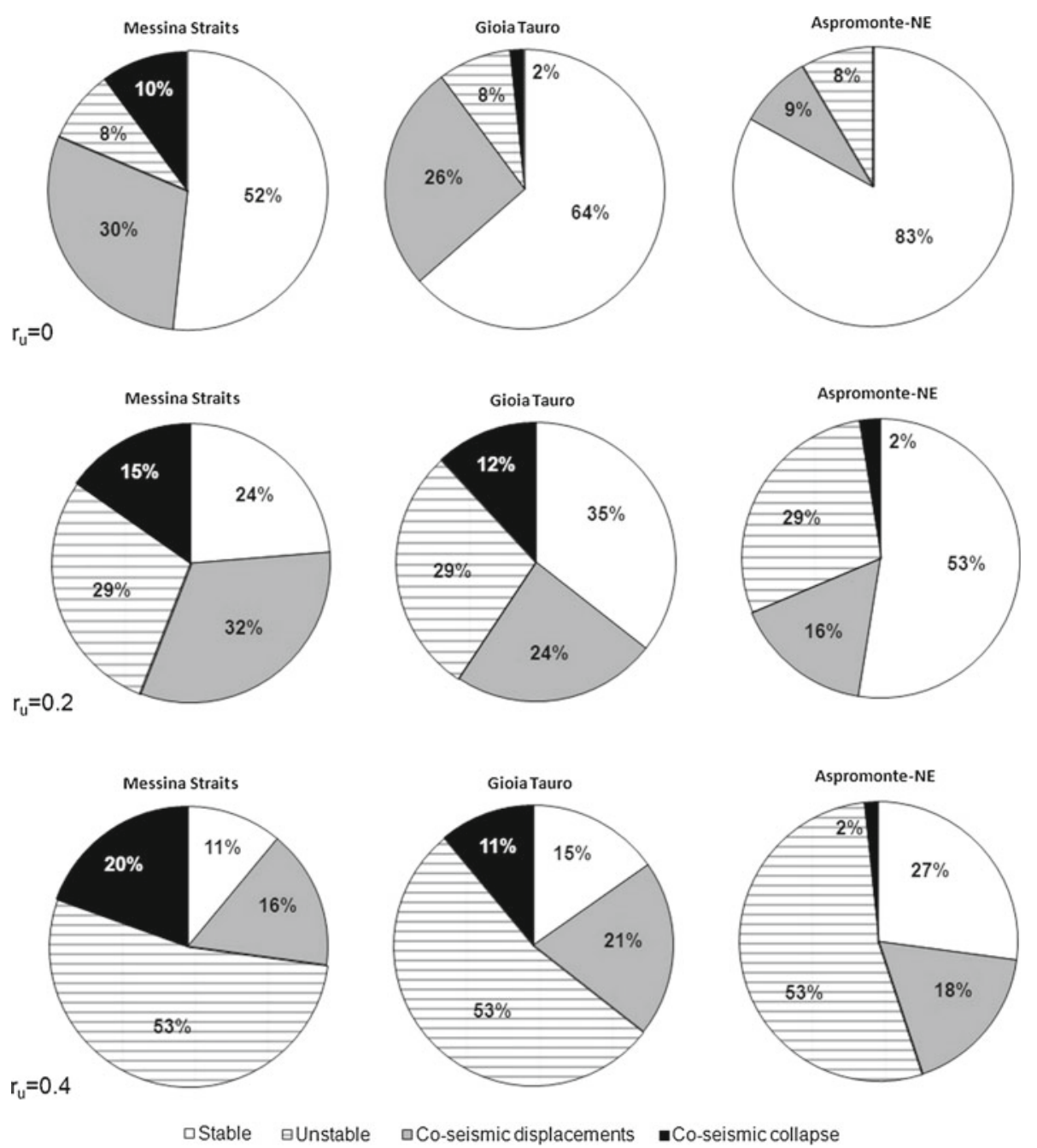

Fig. 8 Percentage of the earthquake-reactivated landslides in the Messina Straits, Gioia Tauro and Aspromonte-NE seismogenic source scenarios

Similar results can be obtained by considering the "Landsliding Index" (equal to the ratio between the landslide-involved area and the total area), which refers to specific coseismic landslide displacements or collapse (Fig. 9). In the case of the most severe earthquake scenario (i.e., the one related to the Messina Straits seismogenic source), the percentage of the landslide area involved in co-seismic collapses varies from 3 to $23 \%$ for the $r_{u}$ varying from 0 to 0.4 .

To properly compute the total percentage of seismically reactivated landslides (including the co-seismic reactivation and the co-seismic collapse), the landslides that are unstable without considering a seismic action were not computed. For the seismic sources located at epicentres closer than $50 \mathrm{~km}$ (Messina Straits and Aspromonte NE), the obtained results show that the percentage of total seismically reactivated landslides approximately decreases from 40 to $20 \%$ for $r_{u}$ varying from 0 to 0.4 (Fig. 10). 

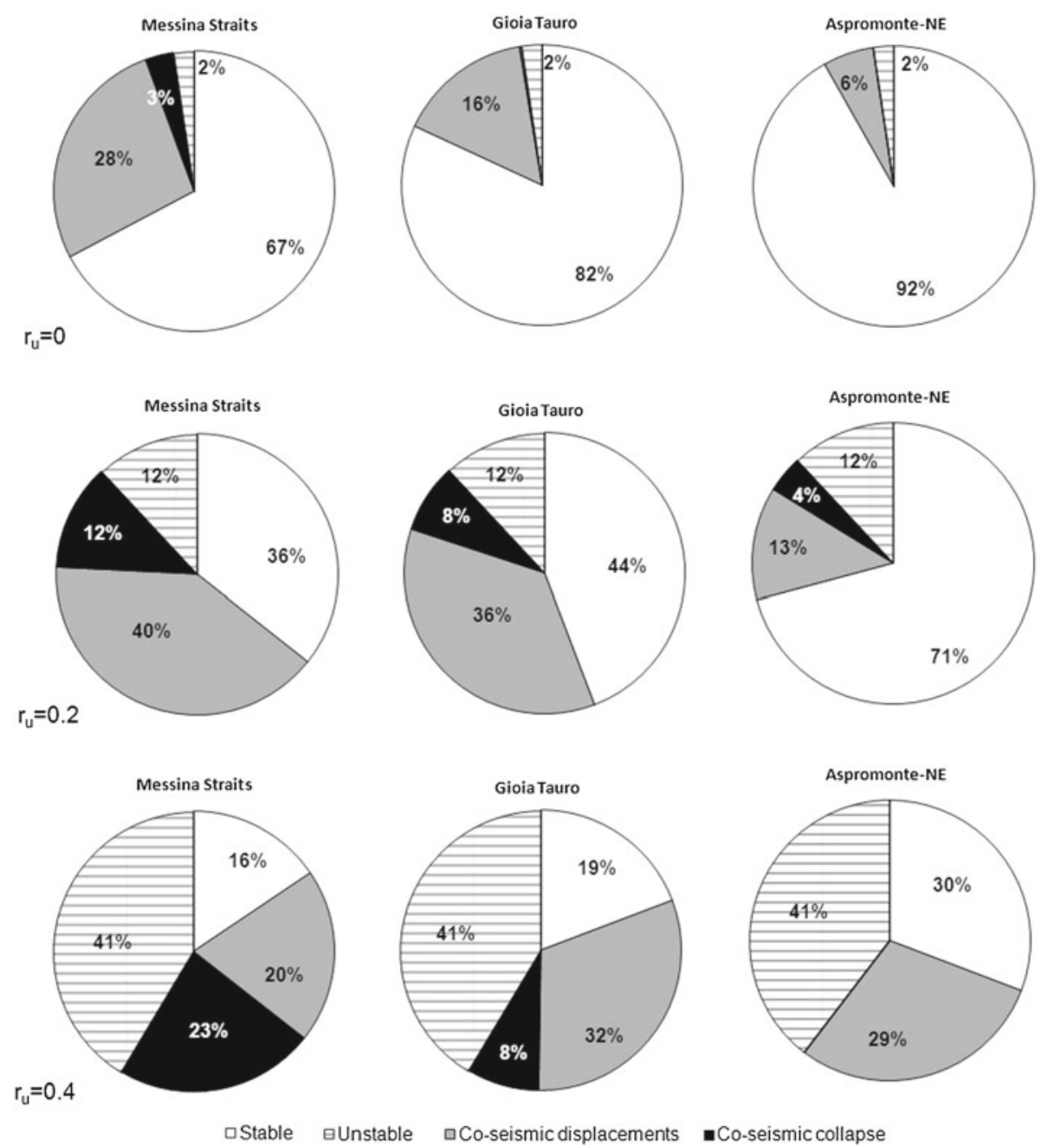

Fig. 9 "Landsliding index" of the earthquake-reactivated landslides in the case of the Messina Straits, Gioia Tauro and Aspromonte-NE seismogenic sources

The exceedance probability of $\mathrm{D}_{\mathrm{N}}$ was derived for each earthquake scenario and for different values of $r_{u}$ (Fig. 11).

Based on this analysis, assuming $r_{u}=0$, for the most severe earthquake scenario (i.e., the Messina Straits), the exceedance probability of co-seismic landslide collapses is approximately $10 \%$, considering the values for co-seismic collapses proposed by Romeo (2000). On the other hand, the probability of co-seismic landslide collapse increases up to $40 \%$ for the Messina Straits earthquake scenario by assuming a very severe admissible value of $r_{u}=0.4$. In the cases of $\mathrm{Mw}<6.0$ earthquake scenarios, the exceedance probability of co-seismic landslide collapses does not exceed $10 \%$ even if an $r_{u}=0.4$ value is assumed.

It is worth noting that Newmark's method does not consider the physical interaction between seismic waves and pre-existing landslide masses; thus, the computed co-seismic displacements can be affected by conservative (in the case of dissipative) systematic errors. 

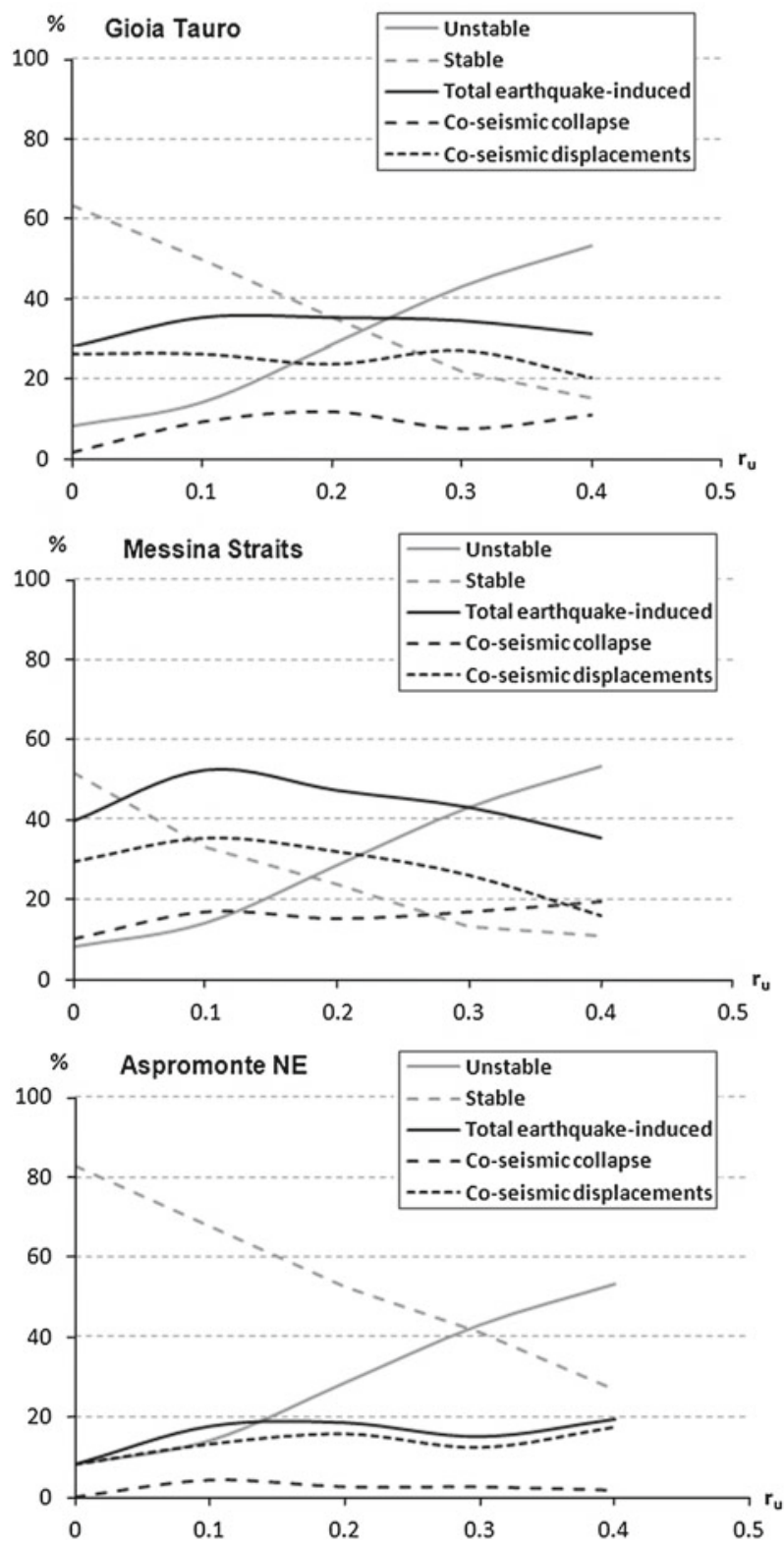

Fig. 10 Percentage distributions of the landslide co-seismic displacements as a function of $r_{u}$ for the earthquake scenarios related to the Messina Straits, Gioia Tauro and Aspromonte-NE seismic sources

Recent studies (Lenti and Martino 2011, 2013) suggest the possibility of taking into account these effects in providing earthquake-induced displacement scenarios for pre-existing landslide masses, i.e., by taking into account the (1) the slope angle, (2) the frequency content of the input and (3) the characteristic periods related to the landslide mass dimensions (both thickness and length). 

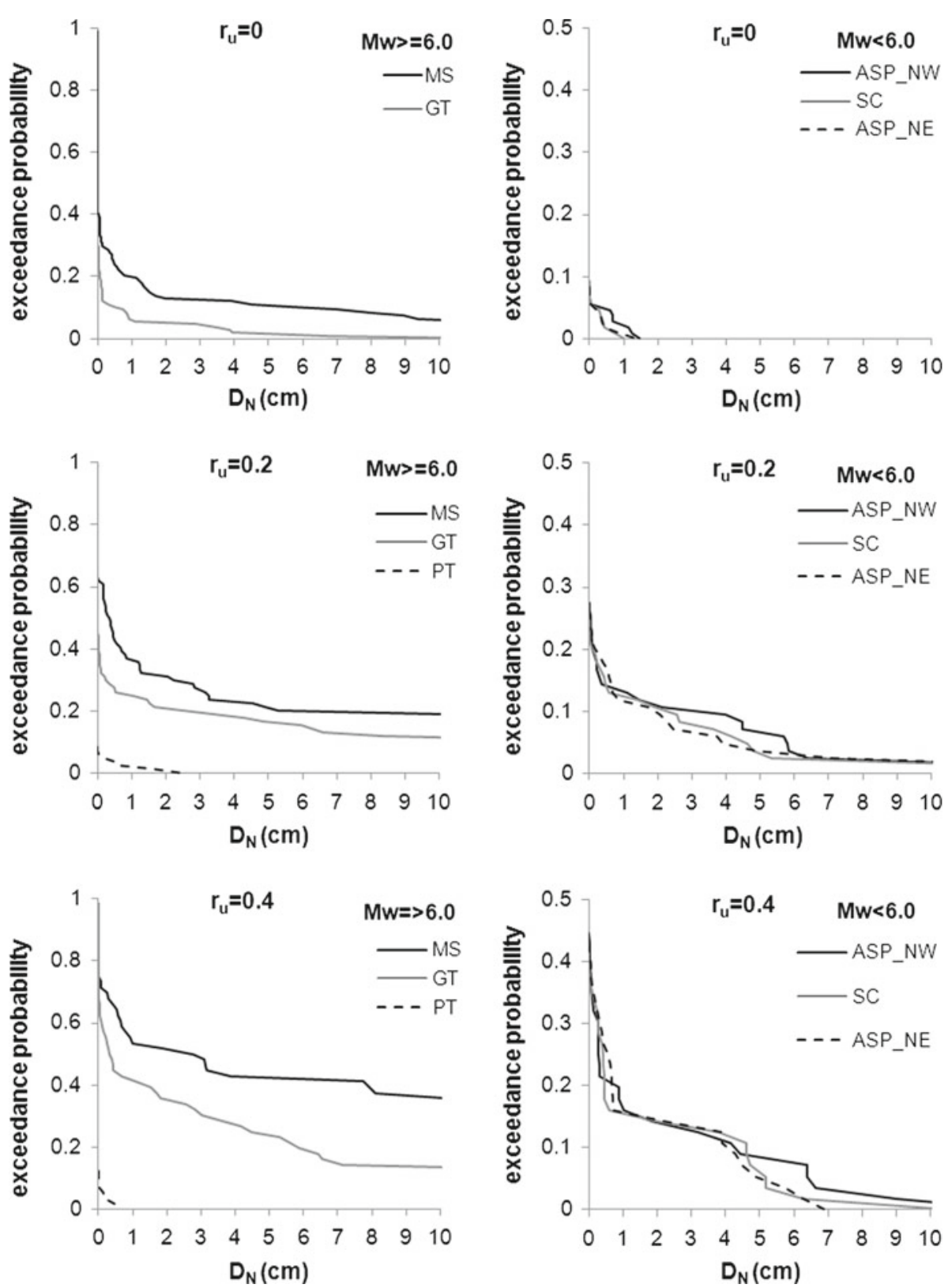

Fig. 11 Exceedance probability of earthquake-reactivated landslide displacements $\left(D_{N}\right)$ in the case of $M w \geq$ 6 (left) and $\mathrm{Mw}<6$ (right) earthquake scenarios (see Table 2 for the seismogenetic source acronyms)

An application of the regression models proposed by Jibson et al. (1998) and Hsieh and Lee (2011) was performed by using the whole dataset of accelerometric time histories computed for each landslide. A multivariate linear regression analysis was carried out with the aim of producing specific regression equations for this area that could be used to estimate coseismic displacement through the interaction between Arias intensity (computed according to 

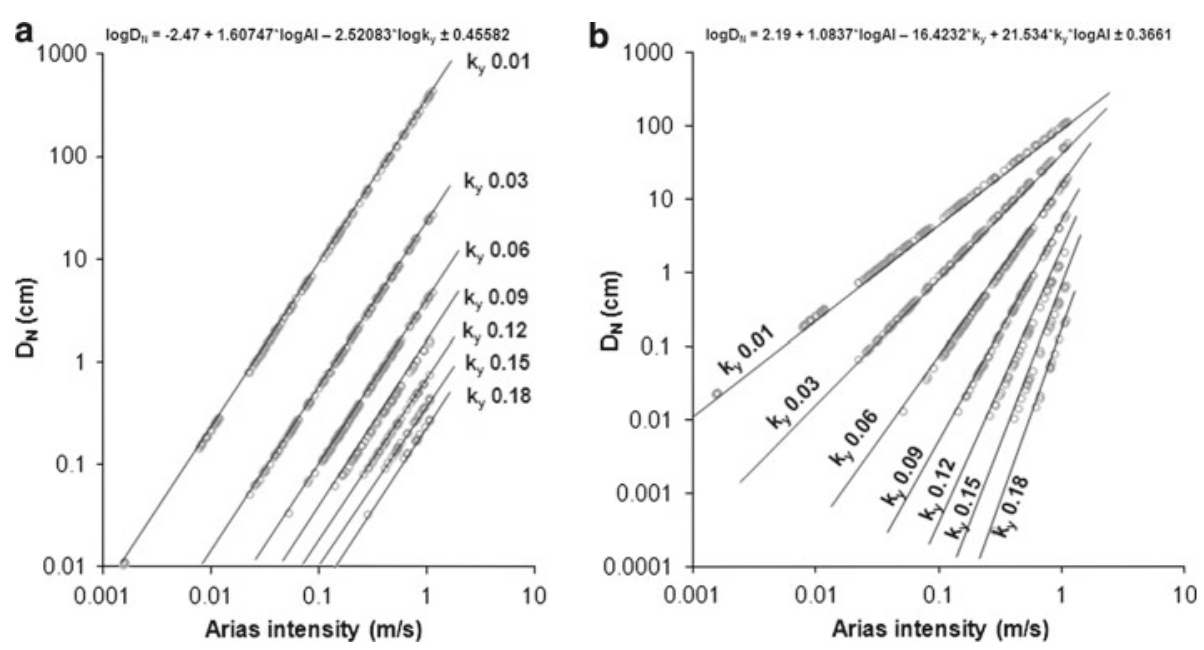

Fig. 12 Empirical co-relations among Arias intensity, $\mathrm{k}_{\mathrm{y}}$ and $\mathrm{D}_{\mathrm{N}}$ obtained for the study area according to the regression equations by Jibson et al. (1998) (a) and by Hsieh and Lee (2011) (b)

Romeo 2000) and the critical acceleration defined for each landslide. A good fit was achieved analysing the co-seismic displacements with respect to the existing models (Fig. 12). In fact, the relation obtained by using the Jibson et al. (1998) model is characterised by an $\mathrm{R}^{2}$ of 0.79 , and the relation derived according to Hsieh and Lee (2011) model has an $\mathrm{R}^{2}$ of 0.86 . We then compared these scenarios of earthquake-induced landslides with the historically documented ground failures due to strong earthquakes in Italy listed in the CEDIT-catalogue (Fortunato et al. 2012; Martino et al. 2012). As it results from the comparison, a good proportionality between the number of earthquake-reactivated landslides in each seismic scenario and the ground failures reported in the catalogue for the strongest earthquakes referring to the same seismic sources was found. Nevertheless, in contrast to the results of the seismic scenarios, a larger number of ground failures are reported in the CEDIT catalogue for the 1783 Calabria earthquake with respect to the 1908 Messina Straits earthquake. One of the main reasons for the discrepancy is that the 1783 earthquake involved a seismic sequence lasting several weeks and migrating from south to north in the Calabria Region (Sarconi 1794), thereby affecting an epicentral area wider than the 1908 event.

\subsection{Uniform probability scenarios of earthquake-reactivated landslides}

Uniform probability (UP) maps of displacements due to earthquake-reactivated landslides were derived based on the expected PGA calculated at the 84th percentile for a return period of 2,475 and 475 years, respectively, reported in the seismic hazard maps by INGV (Meletti and Montaldo 2007; Montaldo and Meletti 2007). The approximately $5 \mathrm{~km}$ spaced grid was queried to attribute the expected PGA to each landslide centroid. The co-seismic UP displacements were computed by using the relations obtained according to the Hsieh and Lee (2011) regression model; at this aim, the Arias intensity value for the expected PGA was attributed to the landslide centroid according to Romeo (2000) and $\mathrm{k}_{\mathrm{y}}$ values were assumed based on the $\mathrm{r}_{\mathrm{u}}-\mathrm{k}_{\mathrm{y}}$ curves obtained for each landslide mass. Figure 13 shows the UP displacements for a return period of 475 years at an $r_{u}$ varying from 0 to 0.4 . The corresponding total percentage of earthquake-reactivated landslides (including co-seismic landslide displacements and 

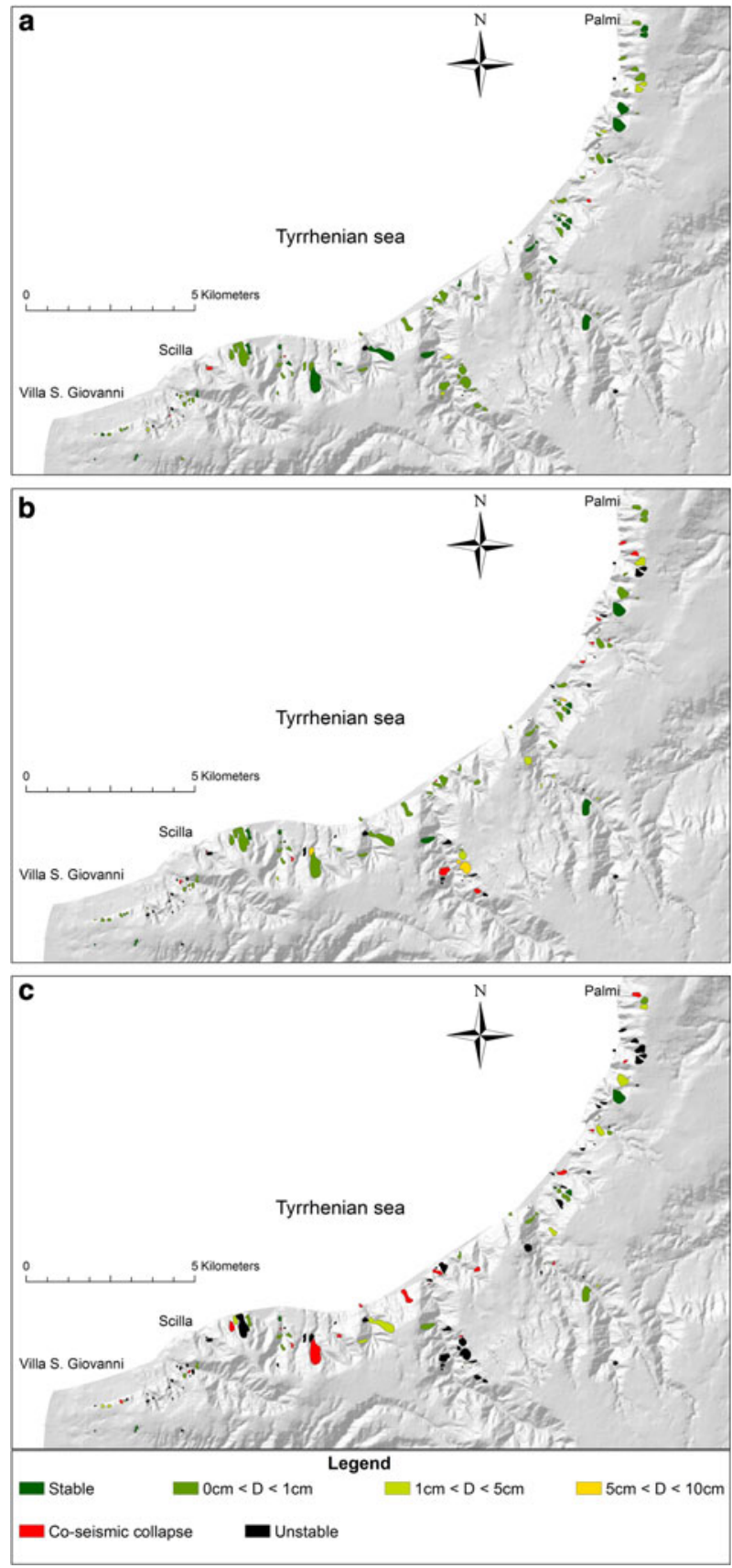

Fig. 13 Maps of the UP Newmark's displacements (D) computed for roto-translational landslides and for a return period of 475 years in the case of $r_{u}=0(\mathbf{a}), r_{u}=0.2(\mathbf{b})$ and $r_{u}=0.4(\mathbf{c})$

co-seismic landslide collapses) for the return periods of 475 and 2,475 years varies from 70 to $90 \%$, respectively, when considering $r_{u}$ values ranging between 0 and 0.4 (Fig. 14). 


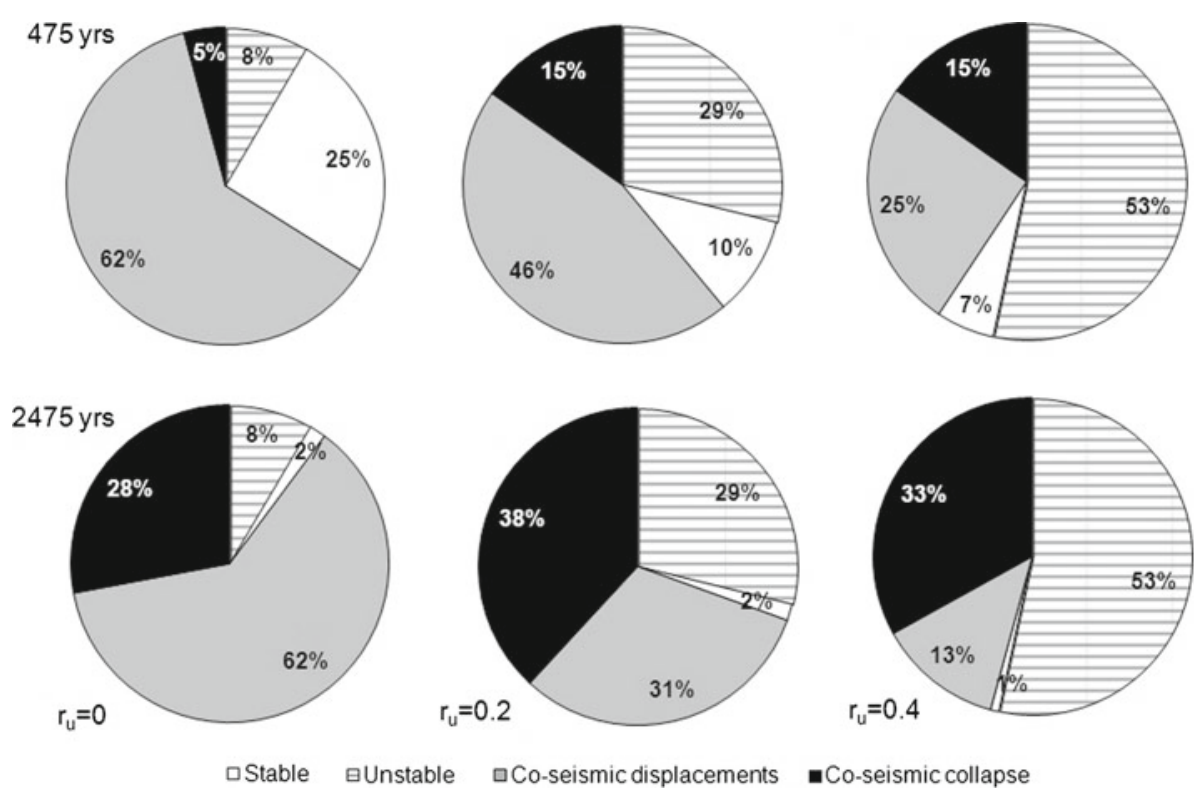

Fig. 14 Percentage distribution of earthquake-reactivated landslides in the 475-years (up) and 2,475-years (down) return-period scenarios and for an $r_{u}$ varying from 0 to 0.4

Moreover, the curves of exceedance probability of earthquake-reactivated landslides were obtained as a function of a return period ranging from 30 to 2,475 years and of $r_{u}$ ranging from 0 to 0.4 (Fig. 15).

The exceedance probability of co-seismic collapses (roughly corresponding to a $\mathrm{D}_{\mathrm{N}}$ higher than $5 \mathrm{~cm}$ ) varies from 5 to $50 \%$ for $\mathrm{r}_{\mathrm{u}}$ increasing from 0 to 0.4 with a return period of 475 years and from 25 to $70 \%$ for $r_{u}$ increasing from 0 to 0.4 with a return period of 2,475 years.

\section{Conclusions}

This paper has addressed the evaluation of landslide potential under seismic shaking in a twofold way: via a rigorous sliding-block method (Wilson and Keefer 1985) and by applying a simplified Newmark's sliding-block analysis (Jibson 2007; Hsieh and Lee 2011). The rigorous approach is preferable since it allows the modeling of real slope conditions in terms of geometry of the sliding mass, but it is practically limited by the required computational effort and the reduced availability of strong-motion records that can reliably reproduce local conditions at landslide sites, unless acceleration time-histories are artificially generated (Miles and Ho 1999). These drawbacks have been overcome by: (1) applying the rigorous analysis to the inventoried landslides alone, that means by analyzing the susceptibility of pre-existing landslides to co-seismic displacements or collapses; (2) deriving the acceleration time-histories for the rigorous sliding-block analysis by attenuating to the landslide sites the strong-motion records selected for each seismic source. Indeed, the latter represents the most valuable approach in applying the rigorous sliding block analysis to a wide area of investigation. In fact, a limited number of actual strong-motion records is required, just the minimum considered to be representative of the stochastic variability of the ground motion due to the seismic source (fixed to five in the present work). Moreover, such a procedure allows preserving the frequency content of the seismic source when a selected ground-motion record is attenuated 
Fig. 15 Exceedance probability of earthquake-reactivated landslide displacements $\left(\mathrm{D}_{\mathrm{N}}\right)$ for an $r_{u}$ varying from 0 to 0.4 in the case of return periods varying (Rt) from 30 to 2,475 years
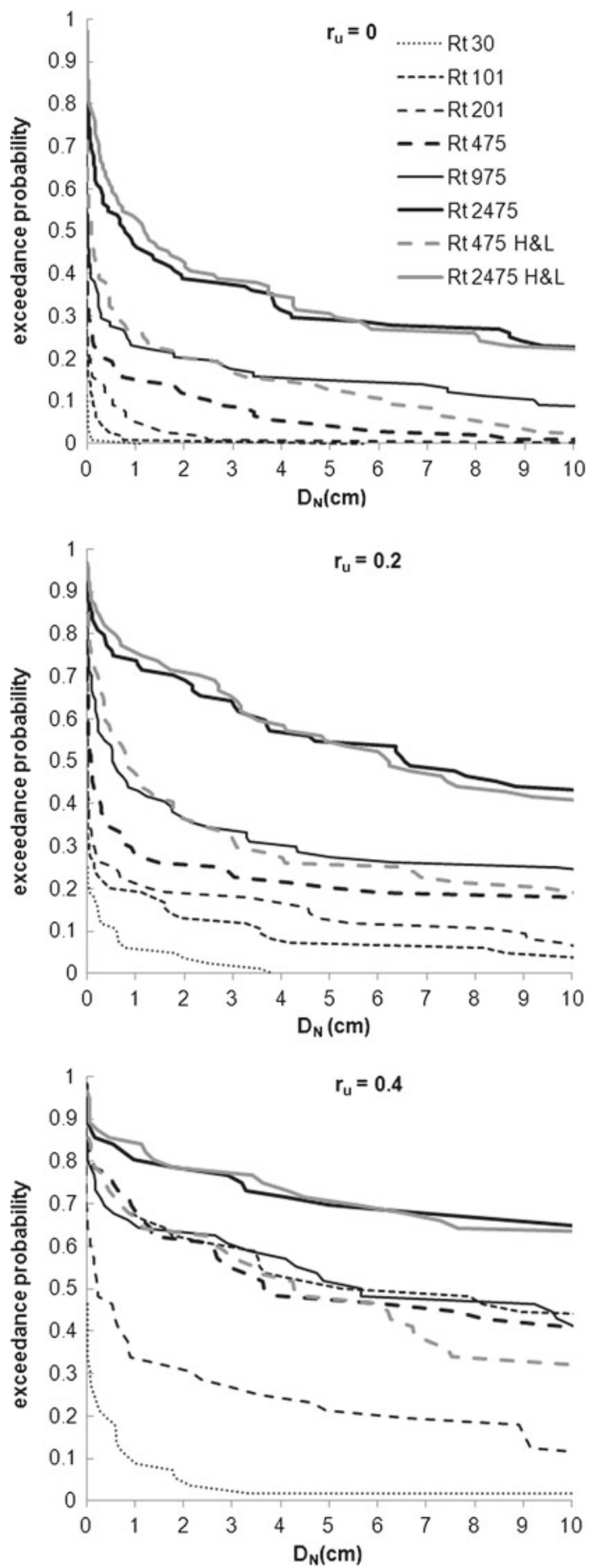
from the source to each landslides site, conversely to the other approach consisting in the selection of site-specific ground-motion records that usually come from different seismic sources due to the limited number of strong-motion records available for the same source at all the distances required by each landslide site.

In this study, a sector of the southern Tyrrhenian part of the Calabria region (Italy) was considered as a test site for evaluating scenarios of seismically induced landslide reactivations. Based on a landslide inventory, 175 landslides were identified, including rock falls and slides, and a landslide susceptibility analysis was performed using a logistic regression technique. This analysis found that the highest concentrations of existing landslides correspond well to the areas characterised by the highest susceptibility to landslides.

For the considered case-study, the co-seismic landslide displacements, computed according to Newmark's sliding-block model, indicate that the Mw $>6$ Messina Straits seismogenic source is the most threatening scenario. For this scenario it results a percentage of earthquake reactivated landslides varying from 31 up to $43 \%$ in terms of areal extent and from 40 up to $46 \%$ in terms of number of landslides; the increasing percentages correspond to increasing pore-water pressures within the landslide masses (i.e. by considering $r_{u}$ varying up to 0.4 which represent very sever water flow conditions) and to an exceedance probability varying from 10 up to $40 \%$.

The here applied methodology attributes a major significance to naturally recorded time histories as well as to landslide inventories, which are actually part of the basic thematic mapping for seismic microzonation studies, which is consistent with the present Italian technical guide-lines, too. Such an approach can be valid for regional-scale study even if it should be stressed that geomechanical properties represent the most difficult parameters to be measured and collected in order to be suitable for large-scale applications.

The merit of the here experienced approach is a promising perspective in the extension of the analysis to first time landslides. This requires a more extensive use of the procedure consisting in attenuating the ground-motion records from the source to landslide-prone areas, when the latter can be so large to overlap with an entire area. In this case, a raster analysis carried out in a GIS-environment would be more suitable, and the application of a simplified Newmark's sliding-block analysis like that shown in this work would be straightforward. Nevertheless, this approach would miss the initial merit of reproducing the actual conditions of the sliding mass, unless the extension of the rigorous sliding-block analysis were restricted to those slopes where a susceptibility analysis had highlighted the highest occurrence probabilities, thus closing the loop from the susceptibility to the triggering of landslides due to earthquakes.

Acknowledgments The authors wish to thank Sara Modanesi for her contributions in performing the slope stability analyses and for her assistance with data processing. This research was funded by the project "POR-Calabria 2000-2006: Movimenti di massa ed attività sismotettonica", resp. Prof. G. Scarascia Mugnozza.

Open Access This article is distributed under the terms of the Creative Commons Attribution License which permits any use, distribution, and reproduction in any medium, provided the original author(s) and the source are credited.

\section{References}

Ambraseys N, Smit P, Berardi R, Rinaldis D, Cotton F, Berge-Thierry C (2000) Dissemination of European strong-motion data. CD-ROM collection, European Council, Environment and Climate Research Programme

Bishop AW (1955) The use of the slip circle in the stability analysis of slopes. Géotechnique 5(1):7-17 
Bozzano F, Lenti L, Martino S, Montagna A, Paciello A (2011) Earthquake triggering of landslides in highly jointed rock masses: reconstruction of the 1783 Scilla rock avalanche (Italy). Geomorphology 129:294-308

Bozzano F, Martino S, Montagna A, Prestininzi A (2012) Back analysis of a rock landslide to infer rheological parameters. Eng Geol 131-132:45-56

Budhu M (2011) Soil mechanics and foundations, 3e. Wiley ISBN 978-0-470-55684-9, pp 780

Capolongo D, Refice A, Mankelow J (2002) Evaluating earthquake-triggered landslide hazard at the basin scale through GIS in the upper Sele River valley. Surv Geophys 23:595-625

Carbone S, Messina A, Lentini F (2008) Note Illustrative della carta geologica d'Italia alla scala 1:50.000: Foglio 601. Dipartimento Difesa del Suolo, Servizio Geologico d'Italia. S.EL.CA. Firenze, pp 170

Chung C, Fabbri F (2003) Validation of spatial prediction models for landslide hazard mapping. Nat Haz 30:451-472

DISS Working Group (2010) Database of Individual Seismogenic Sources (DISS), Version 3.1.1: A compilation of potential sources for earthquakes larger than M 5.5 in Italy and surrounding areas. http://diss.rm. ingv.it/diss/, INGV 2010-Istituto Nazionale di Geofisica e Vulcanologia - All rights reserved

Dumas B, Gueremy P, Raffy J (2005) Evidence for sea-level oscillations by the characteristic thickness of marine deposits from raised terraces of Southern Calabria (Italy). Quatern Sci Rev 24:2120-2136

Fortunato C, Martino S, Prestininzi A, Romeo RW (2012) New release of the Italian catalogue of earthquakeinduced ground failures (CEDIT). Italian J Eng Geol Environ 2:63-74

Gerardi F, Barbano MS, De Martini PM, Pantosti D (2008) Discrimination of tsunami sources (earthquake vs. landslide) on the basis of historical data in Eastern Sicily and southern Calabria. B Seismol Soc Am 98:2795-2805

Ghisetti F (1979) Evoluzione neotettonica dei principali sistemi di faglie della Calabria centrale. Boll Soc Geol Italiana 98:387-430

Ghisetti F (1981) L'evoluzione strutturale del bacino Plio-pleistocenico di Reggio Calabria nel quadro geodinamico dell' Arco Calabro. Boll Soc Geol Italiana 100:433-466

Ghisetti F (1984) L'evoluzione strutturale del bacino plio-pleistocenico di Reggio Calabria nel quadro geodinamico dell' arco calabro. Boll Soc Geol Italiana 100:433-466

Graziani L, Maramai A, Tinti S (2006) A revision of the 1783 Calabrian (Southern Italy) tsunamis. Natl Haz Earth Syst Sci 6:1053-1060

Guarnieri P, Di Stefano A, Carbone S, Lentini F, Del Ben A (2004) A multidisciplinary approach to the reconstruction of the quaternary evolution of the Messina Straits area. In: Pasquare' G, Venturini C (eds) Mapping geology in Italy. APAT, Roma, pp 45-50

Hoek E, Carranza-Torres C, Corkum B (2002) Hoek-Brown failure criterion, 2002, 2nd edn. In: Proceedings of the North American Rock Mechanics Society, Toronto, July

Hsieh SY, Lee CT (2011) Empirical estimation of the Newmark displacement from the Arias intensity and critical acceleration. Eng Geol 122:34-42

Hutchinson JN (1988) General report: morphological and geotechnical parameters of landslides in relation to geology and hydrogeology. Proceedings of the 5th International Symposium on Landslides, Lausanne, Switzerland. Balkema, Rotterdam, pp 3-36

ISIDe Working Group INGV (2010) Italian Seismological Instrumental and parametric database: http://iside. rm.ingv.it

ISRM (2007) The Complete ISRM suggested methods for rock characterization, testing and monitoring: 1974-2006. In: Ulusay R, Hudson JA (eds) Suggested methods prepared by the commission on testing methods. International Society for Rock Mechanics, Compilation Arranged by the ISRM Turkish National Group, Ankara, Turkey, p 628

Janbu N (1954) Application of composite slip circles for stability analysis. In: Proceedings of the Fourth European Conference on stability of earth slopes 3:43-49

Jibson RW, Harp EL, Michael JM (1998) A method for producing digital probabilistic seismic landslide hazard maps: an example from the Los Angeles, California Area. U.S. Geological Survey Open-File Report 98-113, p 17

Jibson RW (1993) Predicting earthquake-induced landslide displacement using Newmark's sliding block analysis. Transportation Research Board, National Research Council, Washington D.C. TR record 1411:9-17

Jibson RW, Harp L, Michael JA (2000) A method for producing digital probabilistic seismic landslide hazard maps. Eng Geol 58:271-289

Jibson RW (2007) Regression models for estimating coseismic landslide displacement. Eng Geol 91:209-218

Lee S, Talib JA (2005) Probabilistic landslide susceptibility and factor effect analysis. Environ Geol 47:982-990

Lenti L, Martino S (2011) The interaction of seismic waves with step-like slopes and its influence on landslide movements. Eng Geol 126:19-36 
Lenti L, Martino S (2013) A parametric numerical study of the interaction between seismic waves and landslides for the evaluation of the susceptibility to seismically induced displacements. Bull Seism Soc Am 103(1). doi: $10.1785 / 0120120019$

Lentini F, Catalano S, Di Stefano A, Guarnieri P (2002) Stratigraphical and structural constraints in the Lucanian Apenins (Southern Italy): tool for reconstructing the geological evolution. J Geodyn 34(1):143-160

Luzi L, Pergalani F (1999) Slope instability in static and dynamic conditions for urban planning: the "Oltre Po Pavese" case history (Regione Lombardia-Italy). Nat Hazard 20(1):57-82

Martino S, Prestininzi A, Romeo RW (2012) An upgrade of the Italian catalogue of earthquake-induced ground failures CEDIT. Proc. 15 World Conference on Earthquake Engineering, Lisbon (24-28 September), paper. 2419

Mathew J, Jha VK, Rawat GS (2009) Landslide susceptibility zonation mapping and its validation in part of Garhwal Lesser Himalaya, India, using binary logistic regression analysis and receiver operating characteristic curve method. Landslides 6:17-26

Mazzanti P, Bozzano F (2011) Revisiting the February 6th 1783 Scilla (Calabria, Italy) landslide and tsunami by numerical simulation. Mar Geophys Res 32:273-286

Meletti C, Montaldo V (2007) Stime di pericolosità sismica per diverse probabilità di superamento in 50 anni: valori di ag. Progetto DPC-INGV S1, Deliverable D2. http://esse1.mi.ingv.it/d2.html

Miles SB, Ho CL (1999) Rigorous landslide hazard zonation using Newmark's method and stochastic ground motion simulation. Soil Dyn Earthq Eng 18:305-323

Miyauchi T, Dai Pra G (1994) Geochronology of Pleistocene marine terraces and regional tectonics in the Tyrrhenian coast of South Calabria, Italy. II Quaternario 7:17-34

Monaco C, Tortorici L, Nicolich R, Cernobori L, Costa M (1996) From collisional to rifted basins: an example from the southern Calabrian arc (Italy). Tectonophysics 266:233-249

Montaldo V, Meletti C (2007) Valutazione del valore della ordinata spettrale a 1sec e ad altri periodi di interesse ingegneristico. Progetto DPC-INGV S1, Deliverable D3, http://esse1.mi.ingv.it/d3.html

Naeim F, Lew M (1995) On the use of design spectrum compatible time histories. Earthq Spectra 11(1):111-127

Newmark NM (1965) Effects of earthquakes on dams and ambankments. Geotecnique 15:139-159

Rinaldis D, Pugliese A, Martini G, Zini A (2011) Analisi della pericolosità sismica di base. In: Scarascia Mugnozza G (Ed) La pericolosità sismica del Lazio. Italian Journal of Engineering Geology and Environment-Book Series, chapter 3, pp 21-55

Romeo RW, Mari M, Pappafico G, Tiberi PP, Gori U, Veneri F, Tonelli G, Paletta C (2011) Hazard and risk scenarios of landslides triggered by earthquakes. In: Proceedings of the 2 nd World Landslide, Forum, 3-7 October 2011, Rome (Italy)

Romeo RW (2000) Seismically induced landslide displacements: a predictive model. Eng Geol 58(3/4): $337-351$

Sabetta F, Pugliese A (1996) Estimation of response spectra and simulation of nonstationary earthquake ground motions. Bull Seism Soc Am 86(2):337-352

Sarconi M (1794) Historia dé fenomeni del tremuoto avvenuto nella Calabria e nel Valdemone nell'anno 1783. Posti in luce alla Reale Accademia delle Scienze e delle Belle Lettere di Napoli

Saygili G, Rathje EM (2009) Probabilistically based seismic landslide hazard maps: an application in Southern California. Eng Geol 109:183-194

Silva WJ, Lee K (1987) WES RASCAL Code for Synthesizing Earthquake Ground Motion. Miscellaneous Paper S-73-1, Report No. 24 in the Series State-of-the-Art for Assessing Earthquake Hazard in the United States, US Army Engineer Waterways Experiment Station

Skempton AW (1985) Residual strength of clays in landslides, folded strata and the laboratory. Geotechnique 35(1):3-18

Vollmert A, Reicherter K, Silva PG, Fernandez-Steeger TM (2011) Landslide mapping to analyse earthquake environmental effects (EEE) in Carmona, Spain-relation to the 1504 event? $2^{\text {nd }}$ INQUA-IGCP-567 International Workshop on Active Tectonics, Earthquake Geology, (2011) Archaeology and Engineering Corinth, Greece

Wang KL, Lin ML (2010) Development of shallow seismic landslide potential map based on Newmark's displacement: the case study of Chi-Chi earthquake. Taiwan Environ Earth Sci 60:775-785

Wilson RC, Keefer DK (1985) Predicting areal limits of earthquake-induced landsliding, in Ziony, J.I., ed., Evaluating Earthquake Hazards in the Los Angeles Region-An Earth-Science Perspective: U.S. Geological Survey Professional Paper 1360:316-345 